\title{
GEOLOGICAL SURVEY \\ RESEARCH 1964
}

\section{Chapter D}

\section{GEOLOGICAL SURVEY PROFFESSIONAL PAPER 501-D}

Scientific notes and summaries of investigations prepared by members of the Geologic, Conservation, Water Resources, and Topographic Divisions in geology, hydrology, topographic mapping, and related fields

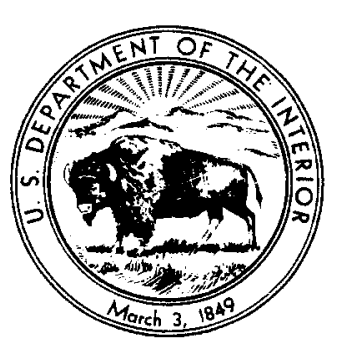

UNITED STATES GOVERNMENT PRINTING OFFICE, WASHINGTON: 1964 


\section{UNITED STATES DEPARTMENT OF THE INTERIOR \\ STEWART L. UDALL, Secretary \\ GEOLOGICAL SURVEY \\ Thomas B. Nolan, Director}

For sale by the Superintendent of Documents, U.S. Government Printing Office, Washington, D. C., 20402 


\section{FOREWORD}

This collection of +3 short papers is the last of the chapters of Geological Survey Research 1964. The papers report on scientific and economic results of current work by members of the Geologic, Conservation, Water Resources, and Topographic Divisions of the U.S. Geological Survey. Some of the papers present results of completed parts of continuing investigations; others announce new discoveries or preliminary results of investigations that will be discussed in greater detail in reports to be published in the future. Still others are scientific notes of limited scope, and short papers on techniques and instrumentation.

Chapter $\mathrm{A}$ of this series presents a summary of results of work done during the present fiscal year.

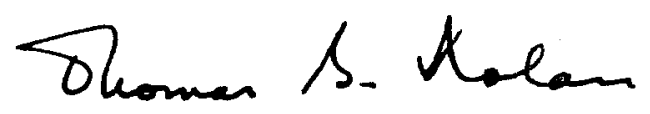

Thomas B. Notan,

Director.

III 


\section{CONTENTS}

\section{GEOLOGIC STUDIES}

\section{Mineralogy and petrology}

Temperatures in the crust and melt of Alae lava lake, Hawaii, after the August 1963 eruption of Kilauea Volcano-a preliminary report, by D. L. Peck, J. G. Moore, and George Kojima. Variation in modes and norms of an "homogeneous" pluton of the Boulder batholith, Montana, by R. I. Tilling ....... Mafic lavas of Dome Mountain, Timber Mountain caldera, southern Nevada, by S. J. Luft.

\section{Structural geology}

Preliminary report on the structure of the southeast Gros Ventre Mountains, Wyoming, by W. R. Keefer

Pre-Fall River folding in the southern part of the Black Hills, South Dakota, by G. B. Gott.

\section{Stratigraphy and paleonfology}

Chinle Formation and Glen Canyon Sandstone in northeastern Utah and northwestern Colorado, by F. G. Poole and J. H. Stewart .

Significance of Triassic ostracodes from Alaska and Nevada, by I. G. Sohn

Middle Devonian plant fossils from northern Maine, by J. M. Schopf

\section{Geochronology}

Radiometric ages of zircon and biotite in quartz diorite, Eights Coast, Antarctica, by A. A. Drake, Jr., T. W. Stern, and H. H. Thomas

\section{Geochemistry}

Qualitative X-ray emission analysis studies of enrichment of common elements in wallrock alteration in the Upper Mississippi Valley zinc-lead district, by J. W. Hosterman, A. V. Heyl, and J. L. Jolly

Suggested exploration target in west-central Maine, by F. C. Canney and E. V. Post...

\section{Geophysics}

Radioactivity- and density-measuring devices for oceanographic studies, by C. M. Bunker Aeromagnetic interpretation of the Globe-Miami copper district, Gila and Pinal Counties, Arizona, by Anna Jespersen - -

54

\section{Economic geology}

Epigenetic uranium deposits in sandstone, by W. I. Finch

The occurrence of phosphate rock in California, by H. D. Gower and B. M. Madsen

The distribution and quality of oil shale in the Green River Formation of the Uinta Basin, Utah-Colorado, by W. B.

Cashion. . . . . . (

Btu values of Fruitland Formation coal deposits in Colorado and New Mexico, as determined from rotary-drill cuttings, by J. S. Hinds.

\section{Marine geology}

Giant submarine landslides on the Hawaiian Ridge, by J. G. Moore.

\section{Engineering geology}

A zone of montmorillonitic weathered clay in Pleistocene deposits at Seattle, Washington, by D. R. Mullineaux, T. C. Nichols, and R. A. Speirer

\section{Quaternary geology and glaciology}

Three pre-Bull Lake tills in the Wind River Mountains, Wyoming-a reinterpretation, by G. M. Richmond ......... Post-hypsithermal glacier advances at Mount Rainier, Washington, by D. R. Crandell and R. D. Miller.

\section{Sedimentation}

Occurrence of dissolved solids in surface waters in the United States, by W. B. Langbein and D. R. Dawdy......... Statistical parameters of Cape Cod beach and eolian sands, by John Schlee, Elazar Uchupi, and J. V. A. Trumbull-----

\section{6}




\section{Analytical rechniques}

An instrumental technique for the determination of submicrogram concentrations of mercury in soils, rocks, and gas, by

W. W. Vaughn and J. H. McCarthy, Jr Determination of mercury in vegetation with dithizone-a single extraction procedure, by F. N. Ward and J. B. McHugh.Ion-exchange separation of tin from silicate rocks, by Claude Huffman, Jr., and A. J. Bartel Determination of carbonate, bicarbonate, and total $\mathrm{CO}_{2}$ in carbonate brines, by.S. L. Rettig and B. F. Jones..........

\section{Cortography}

\section{TOPOGRAPHIC MAPPING}

Mapmaking applications of orthophotography, by M. B. Scher

\section{Ground water}

\section{HYDROLOGIC STUDIES}

Ground-water conduits in the Ashland Mica Schist, northern Georgia, by C. W. Sever Temperature and chemical quality of water from a well drilled through permafrost near Bethel, Alaska, by A. J. Feulner and R. G. Schupp

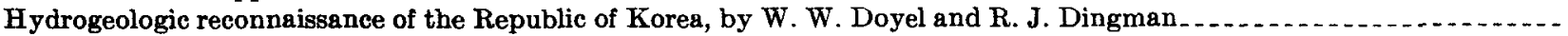
Source of heat in a deep artesian aquifer, Bahia Blanca, Argentina, by S. L. Schoff, J. H. Salso, and José García........ The Carrizo Sand, a potential aquifer in south-central Arkansas, by R. L. Hosman Geohydrology of the Spiritwood aquifer, Stutsman and Barnes Counties, North Dakota, by T. E. Kelly ................ Variation of permeability in the Tensleep Sandstone in the Bighorn Basin, Wyoming, as interpreted from core analyses and geophysical logs, by J. D. Bredehoeft

\section{Ground-water-surface-water relations}

Uniformity of discharge of Muddy River Springs, southeastern Nevada, and relation to interbasin movement of ground water, by T. E. Eakin and D. O. Moore.

Geologic factors affecting discharge of the Sheyenne River in southeastern North Dakota, by Q. F. Paulson.

\section{Surface water}

Magnitude and frequency of storm runoff in southeastern Louisiana and southwestern Mississippi, by V. B. Sauer........Correlation and analysis of water-temperature data for Oregon streams, by A. M. Moore

Engineering hydrology

Elimination of thermal stratification by an air-bubbling technique in Lake Wohlford, Calif., by G. E. Koberg. . . . . . -

Theorefical hydrology

Field methods for determining vertical permeability and aquifer anisotropy, by E. P. Weeks.

Two-variable linear correlation analyses of water-level fluctuations in artesian wells in Florida, by $\mathrm{H}$. G. Healy .

\section{Hydrologic instrumentation}

A periscope for the study of borehole walls, and its use in ground-water studies in Niagara County, N.Y., by F. W. Trainer and J. E. Eddy

\section{INDEXES}

Subject

Author 


\title{
SIGNIFICANCE OF TRIASSIC OSTRACODES FROM ALASKA AND NEVADA
}

\author{
By I. G. SOHN, Washington, D.C.
}

\begin{abstract}
Marine ostracodes are recorded for the first time from sedimentary rocks assigned to the Upper Triassic of Alaska and Middle Triassic of Nevada. These occurrences extend the range of the Cytherellidae downward into the Middle Triassic and tentatively extend the ranges of the Paleozoic Beyrichicopina and Thlipsuracea into the Triassic.
\end{abstract}

Identifiable marine Triassic ostracodes have hitherto not been recorded in North America, although nonmarine forms have been known for more than a century in the continental Triassic beds of the Eastern United States (Jones, 1862). Jones described and illustrated Candona? rogersii and C.? emmonsi from the Triassic of North Carolina and Pennsylvania. These are probably decalcified films of ostracode shells, and are therefore unidentifiable (Sohn, 1958).

Marine ostracodes are present in limited numbers in samples collected for the U.S. Geological Survey by E. G. Sable in 1948 and C. L. Whittington in 1952 from the upper part of the Shublik Formation (Upper Triassic) of the Arctic slope of Alaska. The Foraminifera from this formation were described by Tappan (1951). Harlan Bergquist kindly segregated the ostracodes from the collections.

Silicified marine ostracodes from the Grantsville Formation of late Middle Triassic age (Silberling, 1959) in the Shoshone Mountains, Nev., were sent to me by Prof. David L. Clark, Department of Geology, University of Wisconsin. These specimens were extracted along with conodonts by Mr. Cameron Mosher, University of Wisconsin, from the insoluble residue of a limestone sample collected by N. J. Silberling of the Geological Survey.

Although the ostracodes from Alaska are pyritized and very poorly preserved, and those from Nevada are not perfectly silicified, several genera can be identified.

The samples from Alaska are from the Shublik Formation, on Dodo Creek 2 to 2.3 miles above the junc- tion with the Sadlerochit River, in the foothills of the Sadlerochit Mountains, northern Alaska. The $30 \mathrm{col}-$ lections made contain the following:

Hungarella sp. or spp.

Paracypris? sp. or spp.

Darwinula? sp.

Steinkerns unident.

The sample from Nevada is from USGS Mesozoic loc. M76, in the Grantsville Formation, in the Shoshone Mountains, and contains the following:

\section{Acratia? sp. \\ Carinobairdia? sp.}

Gen. indet. Bairdiidae

Cytherelloidea n. sp. 1

Cytherelloidea n. sp. 2

New genus Thlipsuracea?

Gen. indet. Cytheracea

Gen. indet. Healdiidae

Gen. undet. Beyrichicopina?

Prof. Clark informs me (written communication, 1964) that ostracodes are present in other Triassic samples from Nevada, so that additional collecting will doubtless increase the list. The available information, though meager, is of interest because it begins to fill the gap in the knowledge of Triassic ostracodes and the relation of Paleozoic to post-Paleozoic ostracode groups.

Figure 1 shows the current interpretation of the range and affinities of superfamilies and higher cxtegories of the Ostracoda, upon which is superposed the information obtained from this study. SylvesterBradley (1962) discussed the classification and suggested alternate groupings. The stratigraphic ranges of the groups as illustrated by Scott and SylvesterBradley in Moore (1961) are indicated by dashed lines in the Triassic, with the exception of the family Cytherellidae which extends down to the Upper Triassic. 


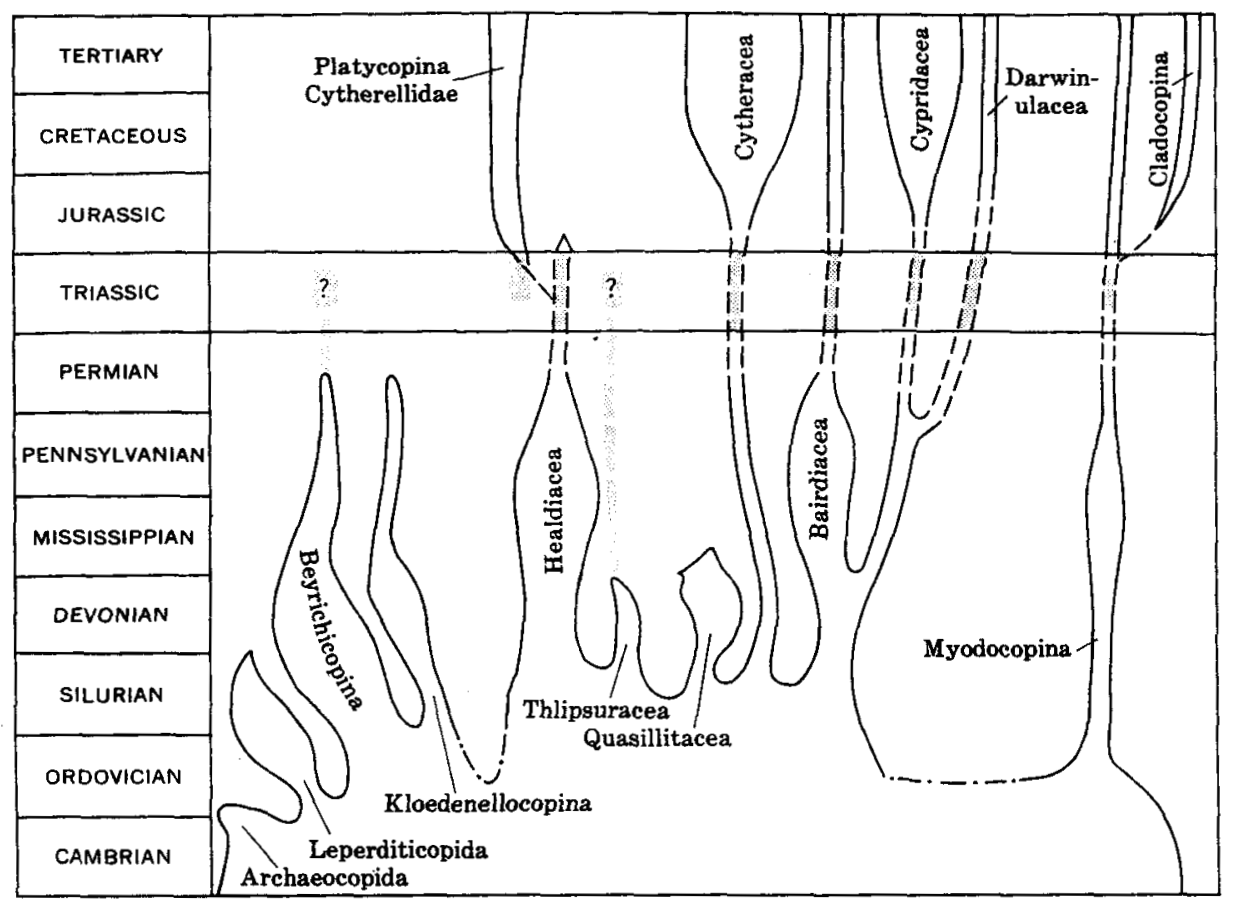

FIGURE 1.-Diagram showing stratigraphic distribution and inferred relations of the superfamilies and higher categories of Ostracoda, after Scott and Sylvester-Bradley, in Moore (1961, figs. 32 and 34). Stippled pattern shows age revisions discussed in text.

More recently, Hartmann discussed the phylogeny of Ostracoda and published a diagram (1963, p. 28, text fig. 8) in which the entire scheme is shown by dashed lines through the Triassic System.

The reasons for the revisions shown by the stippled pattern on figure 1 are given below:

\section{Suborder Beyrichicopina}

Kollmann (1963, p. 144-146) recorded Kirkbyidae? indet., a family that is included in the Byrichicopina, from the Upper Triassic of the Alps, and Hornibrook (1949) described the Recent family Punciidae that is tentatively placed in this suborder. The specimens from Nevada listed above as gen. undet. Beyrichicopina? substantiate the extension of the range of this suborder into the Middle Triassic.

\section{Suborder Platycopina}

The presence of Cytherelloidea in the assemblage from Nevada extends the range of this suborder into the Middle Triassic.

\section{Superfamily Healdiacea}

Hungarella in the Upper Triassic of Alaska, and gen. indet. Healdiidae in the Middle Triassic of $\mathrm{Ne}$ vada are the basis for extending Healdiacea through the Triassic.

\section{Superfamily Thlipsuracea}

The new genus of Thlipsuracea? in the Middle Triassic of Nevada suggests that this taxon has a longer stratigraphic range than has been supposed.

\section{Superfamily Cytheracea}

The presence of an indeterminate genus of Cytheracea in the Middle Triassic of Nevada extends the range of this taxon into the Middle Triassic.

\section{Superfamily Bairdiacea}

Acratia?, Carinobairdia?, and Bairdiidae gen. indet. from Nevada document the presence of this group in the Triassic.

\section{Superfamily Cypridacea}

The Upper Triassic specimens from Alaska, identified is Paracypris? sp. or spp., are very poorly preserved. The fact that Styk (1962, p. 733) listed without illustrating Paracypris sp. from the Muschelkalk of Poland supports the extension of this superfamily into the Triassic.

\section{Superfamily Darwinulacea}

Although the identification of Damoinula in the Upper Triassic of Alaska is based on extremely poorly preserved specimens, the genus has been recorded many 
times from the Triassic in Europe. Drawings of the diagnostic muscle scar of Darwinulacea by Beutler and Gründel (1963, pl. 7a, fig. 3) firmly establish the occurrence of this superfamily in the Triassic.

\section{Suborder Myodocopina}

Although several fragments in the assemblage from Nevada might possibly represent myodocopid ostracodes, they are inadequate for positive identification and are not mentioned in the faunal list. However, the description and illustration of Cypridina balbersteinensis Kittl in Trauth (1918) from the Middle Triassic, and $C$. tonkinensis Patte (1926) from Upper Triassic supports the inclusion of this taxon in the Triassic.

\section{REFERENCES}

Beutler, Gerhard, and Grïndel, Joachim, 1963, Die Ostracoden des Unteren Keuper im Bereich des Thüringer Beckens: Freiberger Forschungshefte, C 164, p. 33-92, 9 pls.

Hartmann, Gerd, 1963, Zur Phylogenie und Systematik der Ostracoden: Zeitsch. zool. Syst. Evolutionsforsch. v. 1, 154 p., 35 figs.

Hornibrook, N. de B., 1949, A new family of living Ostracoda with striking resemblances to some Paleozoic Beyrichiidae: Royal Soc. New Zealand Trans., v. 77, pt. 4, p. 469-471, pls. $50,51$.

Jones, T. R., 1862, North American Lower Mesozoic Cypridae. Appendix in A monograph of fossil Estheriae: Palaeontogr. Soc. London, p. 123-127, pl. 5, text fig. 12.
Kollmann, Kurt, 1963, Ostracoden aus der alpinen Trias II. Weitere Bairdiidae: Jahrb. Geol. Bundensanst., Wien, $\nabla$. 106, p. 121-203, pls. 1-11, 3 tables, 8 text figs.

Moore, R. C., ed., 1961, Treatise on invertebrate paleontology, pt. Q. Arthropoda, 3. Ostracoda: Geol. Soc. America and Unir. Kansas Press, 442 p., 334 figs.

Patte, Etienne, 1926, Etudes paléontologiques relatives a la géologie de l'Est du Tonkin (Paléozoĩque et Trias) : Service Géologique de l'Indochine, Bull., $\nabla .15$, fasc. 1, 240 p., 12 pls.

Silberling, N. J., 1959, Pre-Tertiary stratigraphy and Upper Triassic paleontology of the Union district, Shoshone Mountains, Nevada: U.S. Geol. Survey, Prof. Paper 322, 67 p., 9 pls., map [1960].

Sohn, I. G., 1958, Chemical constituents of ostracodes; some application to paleontology and paleoecology: Jour. Paleontology, v. 32, p. 730-736.

Styk, Olga, 1962, Triassic microfauna in borings of Sulechow and Ksiaz [abs.] : Poland Inst. Geol. Kwartalnik Geol., v. 6, no. 4, p. 732-733.

Sylvester-Bradley, P. C., 1962, The taxonomic treatment of phylogenetic patterns in time and space, with examples from the Ostracoda in David Nicols, ed., Taxonomy and geography: Systematic Assoc. Pub. 4, London, p. 119-133, 4 figs.

Tappan, Helen, 1951, Foraminifera from the Arctic slope of Alaska ; General Introduction and pt. 1, Triassic Foraminifera : U.S. Geol. Survey Prof. Paper 236-A, 20 p., 5 pls.

Trauth, Friedrich, 1918, Uber einige Krustazeenreste aus der mediterranen Trias: Vienna Naturhistirisches Hofmuseums, Annalen, v. 32, p. 172-192, 1 pl. 


\title{
TEMPERATURE AND CHEMICAL QUALITY OF WATER \\ FROM A WELL DRILLED THROUGH PERMAFROST \\ NEAR BETHEL, ALASKA
}

\author{
By ALVIN J. FEULNER and ROBERT G. SCHUPP, \\ Anchorage, Alaska, Palmer, Alaska
}

Work done in cooperation with the U.S. Air Force, Alaskan Air Command

\begin{abstract}
A water well drilled on the Kuskokwim delta near Bethel, Alaska, obtained potable water beneath 603 feet of permafrost. Temperature of the subpermafrost water was $33.2^{\circ} \mathrm{F}$. Chemical similarity of well water to water from the Kuskokwim and Yukon Rivers suggests recharge from either of these rivers through unfrozen zones in the delta deposits.
\end{abstract}

A water well, 622 feet deep, drilled in delta deposits of the Kuskokwim River at a military installation near Bethel (fig. 1) produced water from beneath permafrost 603 feet thick. Located on the older part of the delta, which has been trenched by modern streams, the well site (well 2) is about 175 feet above mean sea level (fig. 2). According to Waller (1957, p. 4) the area is underlain by clay, silt, sand, and some gravel, and the deposits generally are coarser with depth. Waller (1957) also reports that the deposits of coarse sand and fine gravel penetrated in the drilling of wells in and near Bethel are lenticular and cannot be correlated from one well to another.

\section{WELL DRILLING AND TESTING}

The materials penetrated in drilling well 2 , as reported by the U.S. Army Engineers, Alaska District, consist of interbedded sandy silt, silty fine sand, fine sand, and pebbly sand (fig. 3). All these materials are believed to be of deltaic origin. The depth to which the deltaic deposits extend at the well site is not known, but in the general vicinity of the well the total thickness of the deltaic deposits ranges from 450 to nearly 1,000 feet ('T. L. Péwé, oral communication, 1963). Permafrost at well 2 extends to a depth of 603

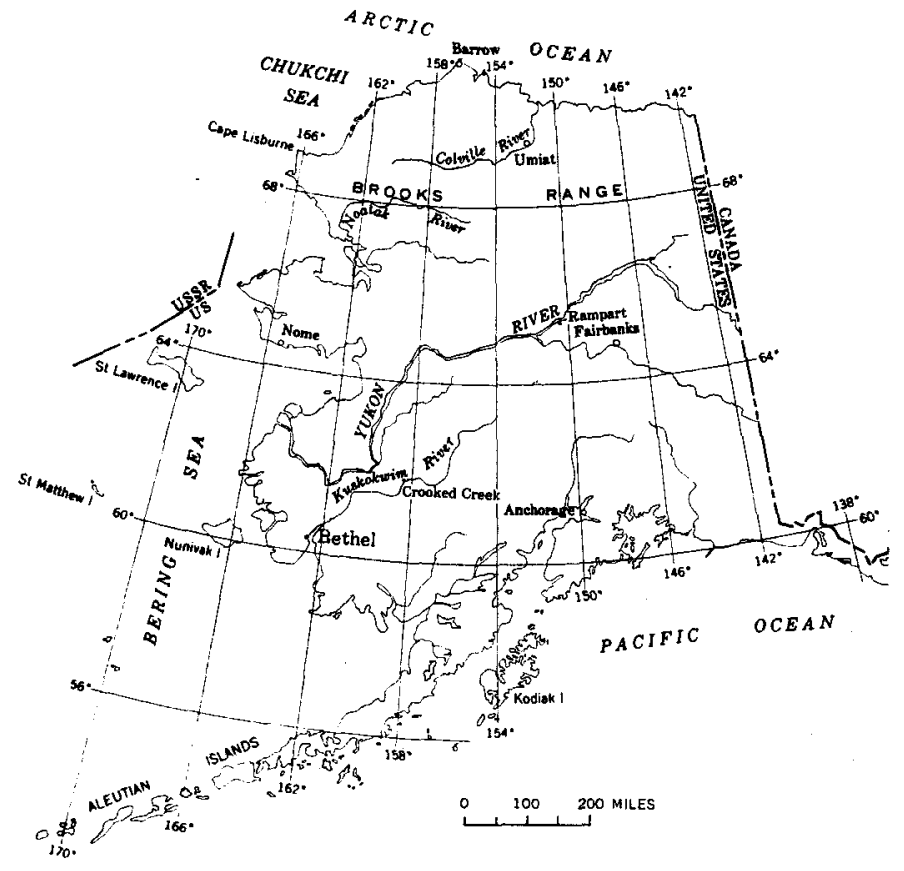

Figdre 1.-Map of Alaska, showing areas referred to in text.

feet. When the drill reached the base of permafrost, a slurry of water, sand, and wood fragments surged up the hole, filling it to within about 350 feet of the surface. One fragment of wood, believed to have come from just below the base of permafrost, has been dated by the carbon-14 method as older than 34,000 years (Ives and others, 1964, sample W-1287).

After well 2 had been drilled to a depth of 662 feet, the interval between 626 and 651 was screened, the hole was plugged back to the bottom of the screen, 

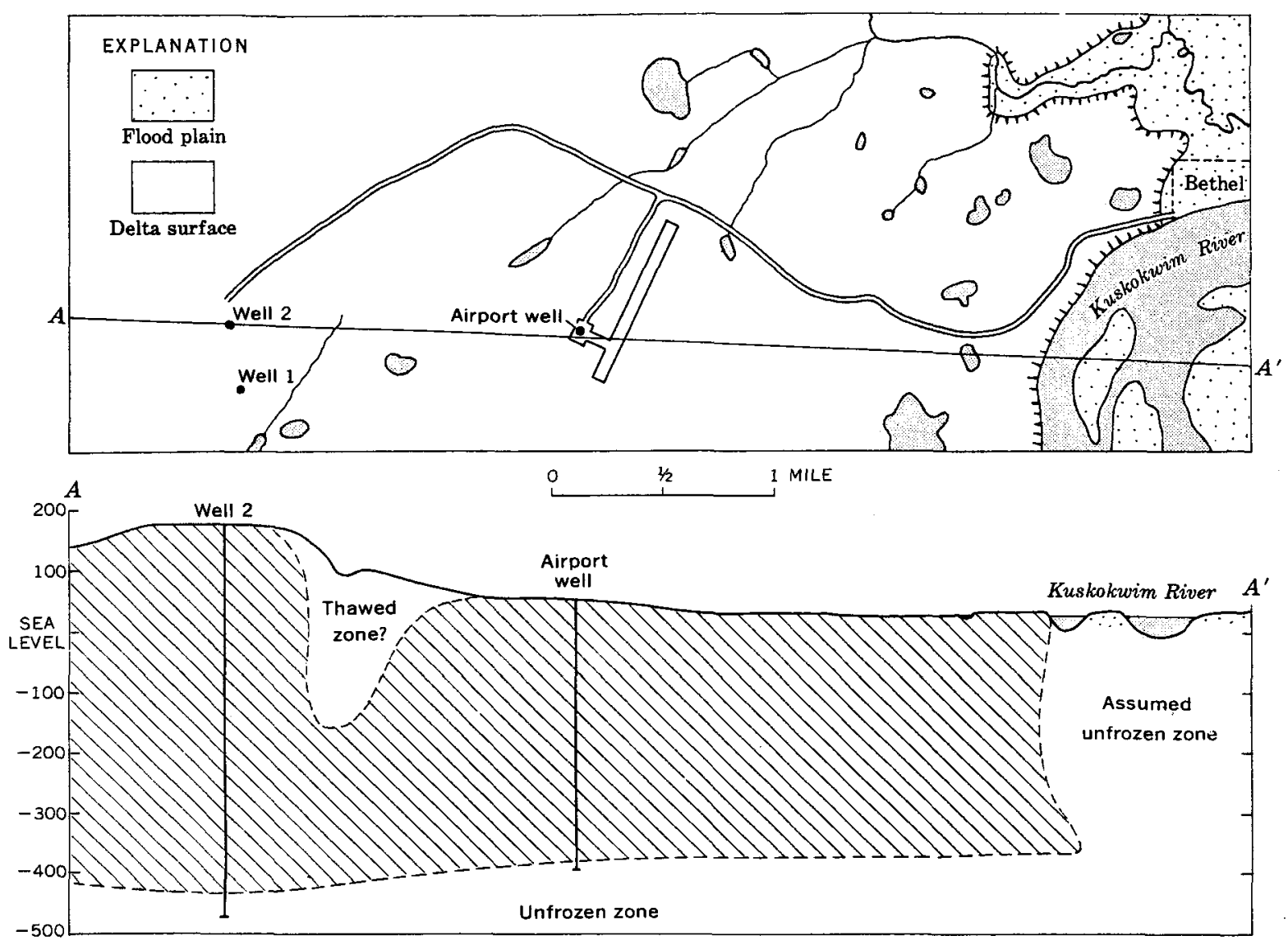

Figdre 2.-Map showing location of wells near Bethel, and cross section showing thickness of permafrost (diagonal lines) in the area.

and the well was developed by surging and bailing. Following the development of the well, the static water level stood 136 feet below land surface. Because the water level stood so high in the permafrost (more than 450 feet), it was necessary to introduce about $11 / 2$ gallons per minute of warmed water into the well to prevent freezing. In early January a pump having a capacity of $12 \mathrm{gpm}$ was installed, and by continuous pumping the water in the well was kept from freezing.

Although the capacity of the pump was small, the pump was used in making a preliminary test. After the well had been pumped continuously for 64 hours at a rate of $12 \mathrm{gpm}$, the water level stood at 146.7 feet below land surface, or 10.7 feet below static level, indicating a specific capacity of about $1 \mathrm{gpm}$ per foot. of drawdown.

At intervals of 12,24 , and 36 hours after completion of the preliminary test, the temperature of the water in the well was measured at increments of depth from the water surface to the base of the screen. A Whitney underwater thermometer, rated accurate to within $0.1^{\circ} \mathrm{F}$, was used to make the measurements. The three sets of water temperatures were averaged and are presented on figure 3 . The greatest deviation from the average of the three temperature determinations at any given depth was $0.1^{\circ} \mathrm{F}$. The average temperature of water opposite the permafrost zone was $31.8^{\circ} \mathrm{F}$, but the average of the three readings at the different depths within this zone ranged from $31.8^{\circ}$ to $31.9^{\circ} \mathrm{F}$. All temperatures below a depth of 605 feet were the same on all three readings. The maximum water temperature recorded was $33.2^{\circ} \mathrm{F}$ at a depth of 620 feet. The presence of a solid casing rather than a screen at this depth is not believed to have had any significant effect in the temperature determinations.

The temperature at which water in the well wo: freeze inward opposite the permafrost zone was not determined. Horrever, during construction of the well, the water froze inward from the casing during the night when drilling was not in progress. Collars of ice, more than an inch thick, formed in the casing at a deptl of about 300 feet during the period between midnight and 8 o'clock in the morning. After completion of drilling and development of the well, convection currents between warmer water at the base 

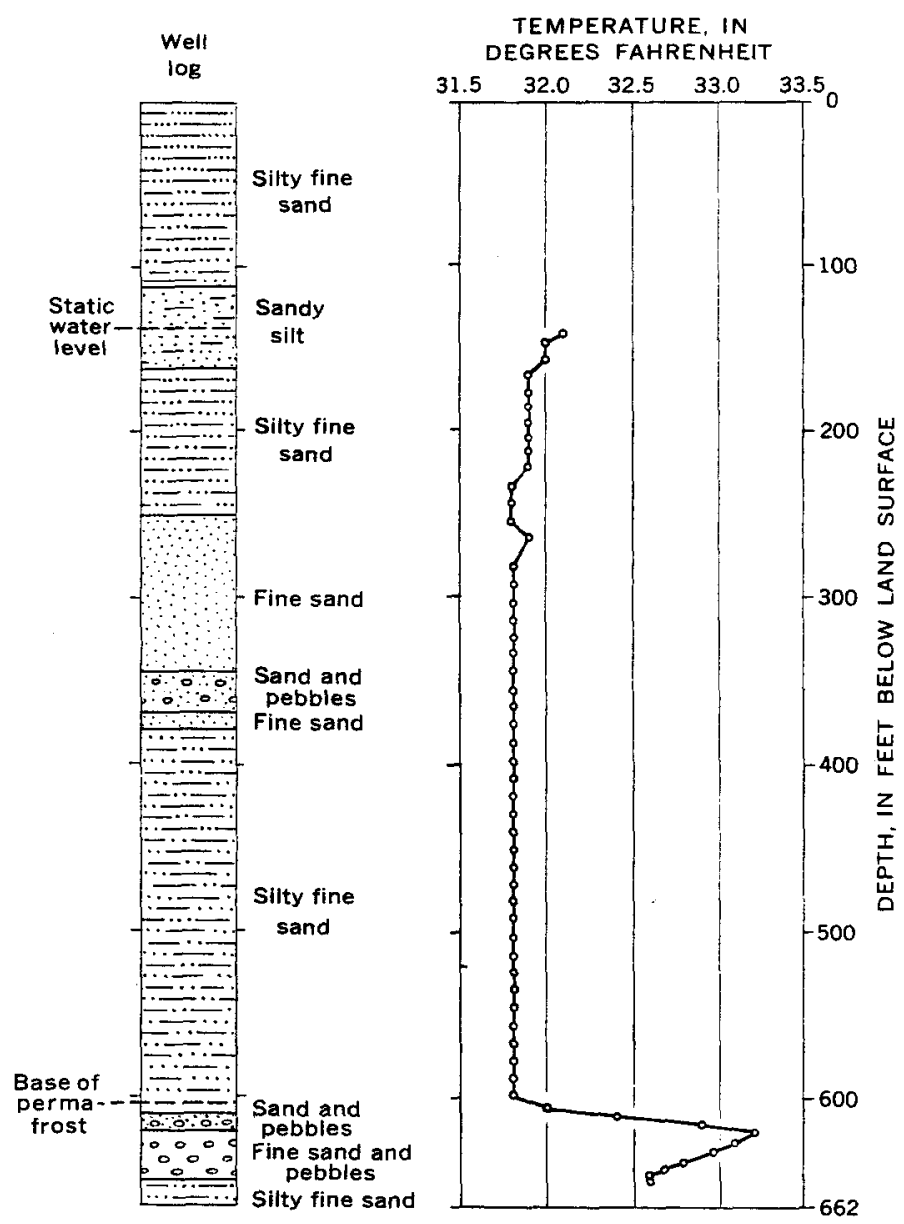

Figure 3.-Generalized lithologic log and water-temperature $\log$ of deep well near Bethel, Alaska. Temperature measurements made on January 21 and 22, 1963. Each circle on the water-temperature log indicates a separate temperature measurement.

of permafrost and the cold water above may have kept the water from freezing inward during the period in which the temperature measurements were made. After the last set of temperature measurements were made, warm water from storage was again introduced into the well to prevent freezing.

About a week after the conclusion of the preliminary pumping test a larger pump was installed and a second pumping test made. This test lasted only 10 hours because the electric water-level tape, used tp measure depth to water, became entangled in the pump column. A third and final test was begun 2 days later, and pumping continued for 33. hours. During this test the average rate of pumping was about 45 gpm and the drawdown was about 40 feet, again indicating a specific capacity of about $1 \mathrm{gpm}$ per foot of drawdown.

\section{PERMAFROST}

In the immediate vicinity of Bethel the base of permafrost is about 350 below sea level (Waller, 1957, fig. 3). The greater thickness of the permafrost in the vicinity of well 2 is probably due to the fact that the ground surface at the site is about 150 feet higher than at Bethel. Beneath rivers and old meanders, and in areas where tributaries have flowed in comparatively recent times, the permafrost has partly thawed from the surface downward, or has been removed entirely by downward thawing. At the site of well 1 , about 1,500 feet south of well 2, permafrost was reported at depths of from 22 to 42 feet and from 280 to at least 378 feet, where drilling was stopped. The well was backfilled to 202 feet, and the zone between 192 and 202 feet was screened and developed. According to Waller (1957, p. 5), the report of permafrost from 22 to 42 feet is questionable. Well 1 is in a depression that is believed to have been the channel of a fairly sizable stream which fed the Kuskokwim River within comparatively recent times. This thawed zone is shown on figure 1 between well 2 and the airport well. Elsewhere in the vicinity, permafrost extends from near ground surface to 350 to 425 feet below sea level (fig. 2).

\section{WATER QUALITY}

Three water samples were collected from well 2 for chemical analysis (see accompanying table). The first of these samples was a bailer sample taken when water and sand first entered the hole from a depth of 603 feet. The second was a bailer sample collected about 8 hours after the conclusion of the preliminary pumping test. The third sample was collected about 1 hour before the conclusion of the final pumping test. The analyses show that the well yields a bicarbonate water in which calcium and magnesium are the predominant cations. The dissolved-solids content ranges from 123 to $172 \mathrm{ppm}$.

Also included in the table are analyses of water from well 1, from a 436-foot well at the Bethel airport (fig. 2), from the Kuskokwim River upstream from Bethel, and from the Yukon River. The analysis reported for the Kuskokwim River represents an average of 11 samples taken during 1962 at Crooked Creek, about 145 miles northeast of Bethel, and the analysis for the Yukon River represents an average of 12 samples taken during 1962 at Rampart, about 480 miles northeast of Bethel. 
Chemical analyses of water from wells near Bethel and from the Yukon and Kuskokwim Rivers

[Mineral constituents in parts per million. Analyses by the Quality of Water Branch, U.S. Geological Survey, Palmer, Alaska]

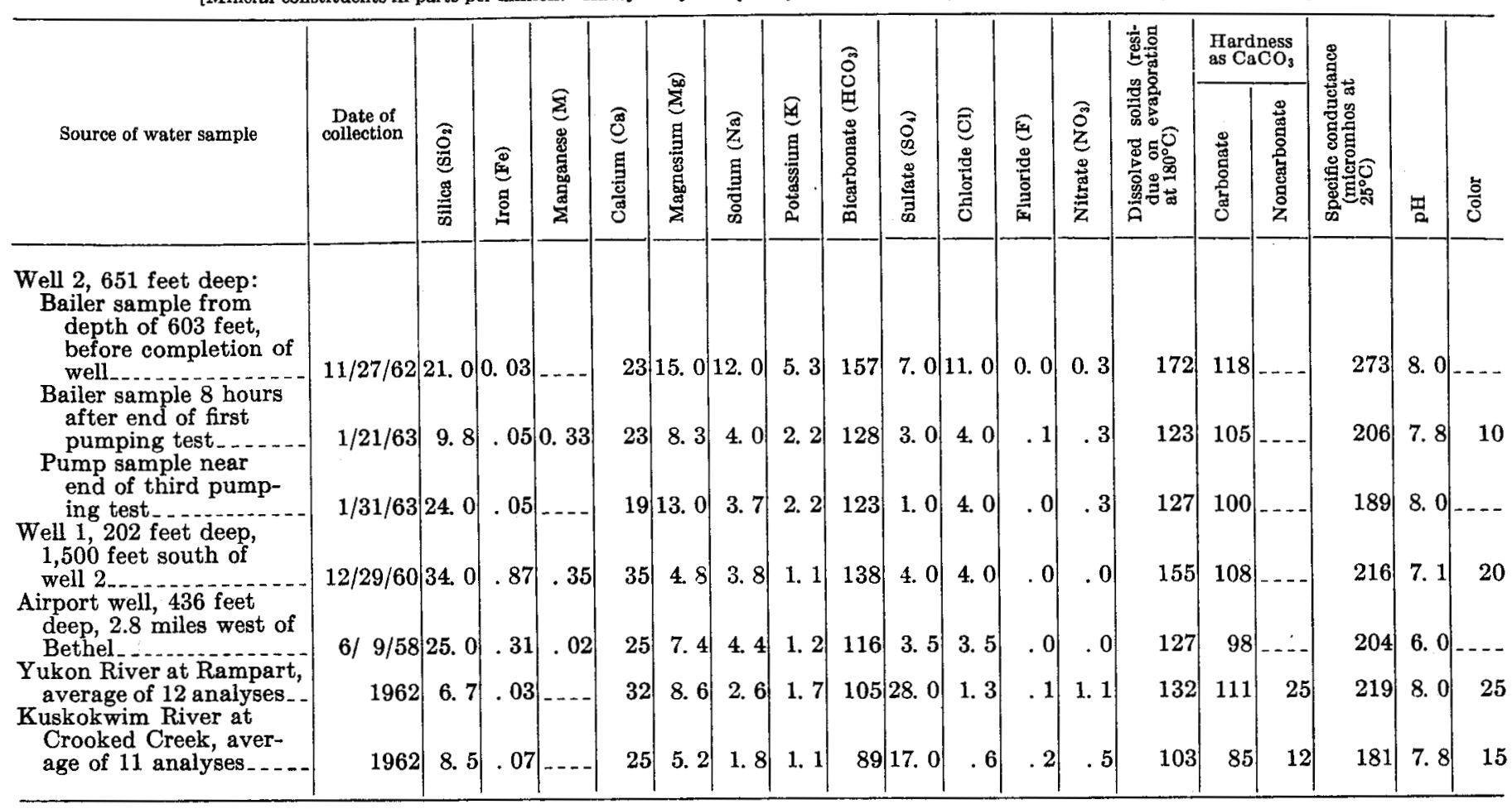


Chemical analyses of water from wells near Bethel and from the Yukon and Kuskokwim Rivers

[Mineral constituents in parts per million. Analyses by the Quality of Water Branch, U.S. Geological Survey, Palmer, Alaska]

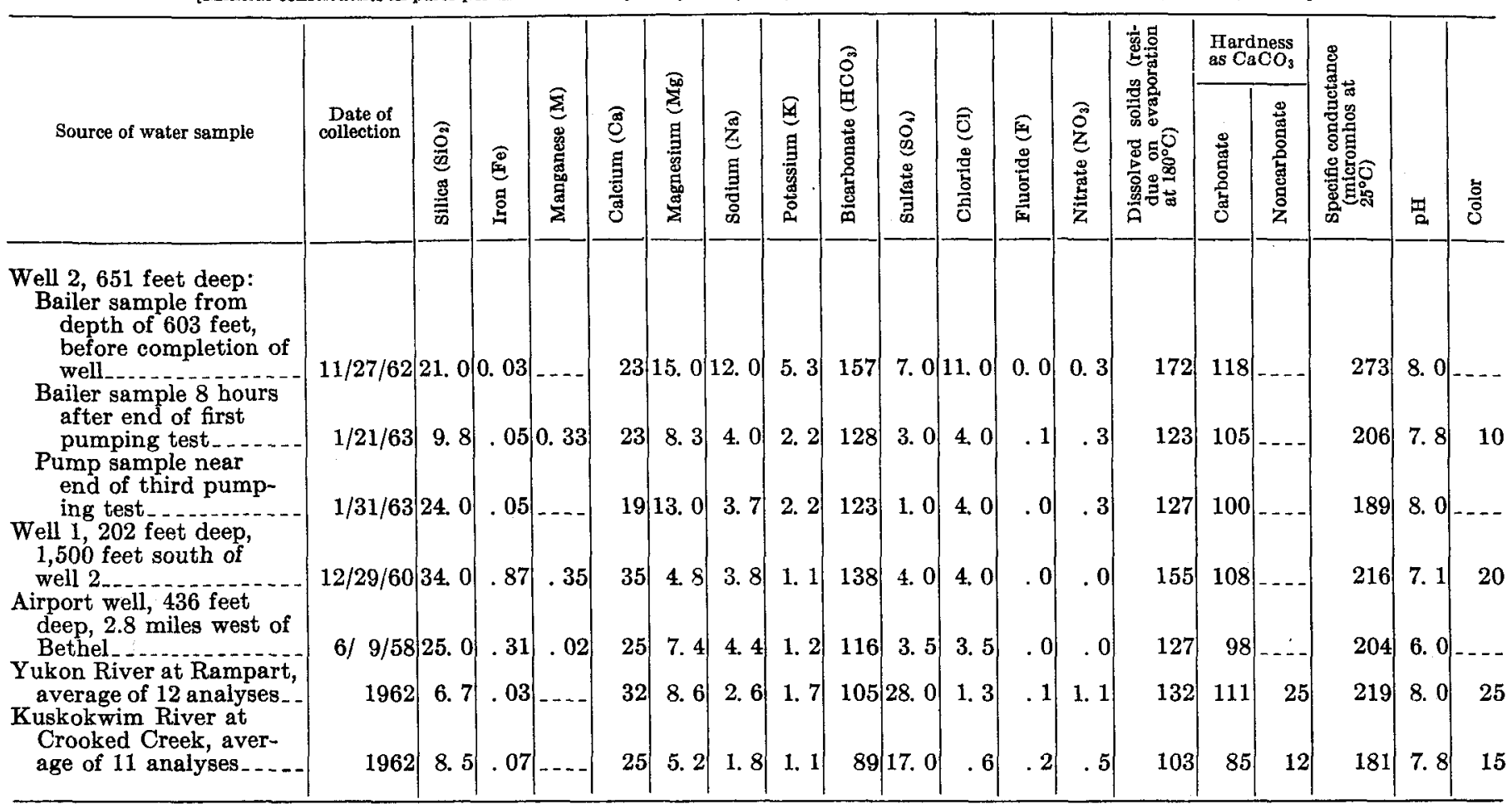

